Jerzy Wiesław Gogola OCD 1

Uniwersytet Papieski Jana Pawła II w Krakowie

\title{
Duchowość osób konsekrowanych w świetle adhortacji Jana Pawła II Vita consecrata
}

Na samym wstępie należy zauważyć, że ograniczenie źródeł tej refleksji do Vita consecrata wcale nie oznacza zubożenia idei duchowości życia konsekrowanego w Kościele posoborowym. Jak to wynika z charakteru wszystkich papieskich adhortacji, ma ona za zadanie „zachętę", pobudzenie do działania, a nie tylko przedstawianie doktrynalnych nowości, jakkolwiek w tym wypadku mamy do czynienia także z nowością. Adhortacja zakłada znajomość całej tradycji Kościoła w kwestii życia konsekrowanego, a jednocześnie prezentuje zagadnienie w nowym stylu i w nowym świetle. Jesús Castellano mówi o dwóch rodzajach nowości: 1) adhortacja nie powtarza treści zawartych już wcześniej w takich dokumentach, jak: Lumen gentium, Perfectae caritatis, Evangelica testificatio, Potissimum institutionis, Życie braterskie we wspólnocie, raczej przedstawia sytuację życia konsekrowanego przy końcu drugiego tysiąclecia i przyjmuje z otwartością propozycje ojców synodalnych zawarte w Instrumentum laboris; 2) cechuje ją bardzo mocna idea komunii ad intra i ad extra życia konsekrowanego: komunia wewnątrz życia konsekrowanego otwarta jest na cały Kościół,

Jerzy Wiesław Gogola, prof. zw., teolog duchowości. Studia teologiczne i specjalistyczne z duchowości na Teresianum w Rzymie oraz na PAT w Krakowie. Kierownik Katedry Historii Duchowości na UPJPII (od 2001), założyciel i dyrektor Karmelitańskiego Instytutu Duchowości w Krakowie (od 1991). Wykładowca teologii duchowości w WSD Karmelitów Bosych (od 1984), na PIZW w Warszawie (1991-2008), UWM w Olsztynie (2005-2008), KID w Krakowie; zatrudniony na UPJPII od roku 2000. 
a także na całą ludzkość ${ }^{2}$. Za Pierem Giordanem Cabrą ${ }^{3}$ można też wskazać na kilka zasadniczych nowości tematycznych:

a) Relacja pomiędzy życiem konsekrowanym a laikatem (VC 54-56). Mówi się wprost o zwrocie i rozpoczęciu pisania nowego rozdziału pod tym względem (VC 54).

b) Miejsce kobiety konsekrowanej w Kościele (VC 57-58). Zgodnie z postulatami synodu adhortacja porusza tę kwestię, dając bardzo pozytywne rozwiązania i wykazując wielką otwartość pod tym względem. Mowa nawet o potrzebie wkładu kobiet w formację kapłanów (VC 58).

c) Ustanowienie komisji w celu studiowania trzech zagadnień: klauzury (rewizja zgodna z początkowym charyzmatem instytutu, ale uwzględniająca postulaty zgłoszone do synodu), instytuty mieszane (postulat, by takie zaistniały) i nowe formy życia ewangelicznego. Chodzi tu głównie o sposób realizacji tych postulatów.

d) Potraktowanie trzech rad ewangelicznych jako odpowiedzi na wyzwania zachodniej cywilizacji (VC 87-91). Osoby konsekrowane mają nie tylko być znakiem sprzeciwu wobec typowych dzisiaj wypaczeń, ale też budować nową kulturę poprzez swój sposób bycia na sposób Chrystusa.

e) Formacja permanentna. Nie jest to nowość jako taka, ale nowe jest potraktowanie tego zagadnienia i przypisanie mu istotnego znaczenia w wypełnianiu zadań przez osoby konsekrowane w dzisiejszym świecie. Wprowadza się terminologię pozwalającą widzieć formację jako jeden proces obejmujący całe życie zakonnika: formacja początkowa i permanentna.

f) Duchowość komunii. Odbija się tu echem eklezjologia komunii, wiodąca prym od Vaticanum II, w oparciu o którą dokonują się wszystkie przemiany w życiu konsekrowanym, które nie tylko jest wyrazem Kościoła-komunii, ale też może w sposób istotny przyczynić się do jego budowania. Bowiem głównie od tego zależy dzieło ewangelizacji (por. VC 74).

Podjęty temat jest bardzo wymagający i szeroki. Przedstawienie go w formie artykułu wymaga ograniczenia refleksji do zaprezentowania ogól-

\footnotetext{
2 Por. J. Castellano Cervera OCD, Dimensione teologica e spirituale della vita consacrata: tradizione, novità, profezia, [w:] Vita consecrata, autori vari, Roma 1996, s. 38-39.

P. G. Cabra, Presentazione del documento ,Vita consecrata”, [w:] L'esortazione apostolica post-sinodale di Giovanni Paolo II "Vita consecrata”. I grandi temi, Roma 1997, s. 21-25.
} 
nych rysów duchowości życia konsekrowanego ${ }^{4}$. Struktura artykułu zostanie ograniczona do trzech zasadniczych punktów. Po ukazaniu znaczenia duchowości życia konsekrowanego jako koniecznego założenia metodologicznego uwzględnimy zasadę ,agere sequitur esse”, by po określeniu tożsamości życia konsekrowanego naszkicować główne rysy jego duchowości, jakie z niej wynikają.

\section{Definicja duchowości życia konsekrowanego}

Sprawa jest o tyle złożona, że chcemy zdefiniować jeden z rodzajów duchowości szczegółowej, podczas gdy już sama teologia duchowości oznacza specjalizację w dziedzinie teologicznej. W tej sytuacji należy uwzględnić najpierw to, co ogólne i stanowi zasadniczą treść ujęcia szczegółowego ${ }^{5}$. Zagadnienie jest na tyle złożone i szerokie, że musimy zadowolić się jedynie prostym stwierdzeniem, iż chodzi nam o synonim życia duchowego, jakie prowadzą osoby konsekrowane. Duchowość życia konsekrowanego będzie oznaczać dla nas styl życia, będący wynikiem bardzo wielu czynników i splotu relacji osobowych i nieosobowych. Człowiek jest istotą zdolną do przekraczania siebie, do samoświadomości, do refleksji nad zaistniałymi faktami i do wyciągania z nich wniosków na dalsze życie. W praktyce jest to złożony i dynamiczny proces składający się z decyzji, postaw i czynów, zależnie od konkretnej sytuacji. Jego opis stanowi zawsze duże uproszczenie. Trzeba się bowiem zadowolić wyliczeniem tych czynników i postaw, które są w proces zaangażowane, jednak życia jako takiego nie da się adekwatnie opisać.

W dwóch słowach należy nawiązać do wzajemnej relacji pomiędzy duchowością ogólną a jakąkolwiek duchowością szczegółową ${ }^{6}$. Istotę życia duchowego można określić jako osobową komunię człowieka z Bogiem zapoczątkowaną i podtrzymywaną przez łaskę. A łaską jest „miłość Boża rozlana w naszych sercach przez Ducha, który został nam dany” (Rz 5, 5). Ten

4 W innym miejscu przedstawiliśmy rozległą syntezę tej problematyki:J. W. Gogola, Oddani Bogu. Teologia i duchowość życia konsekrowanego, Kraków 2013, s. 376.

5 Por. J. W. Gogola, Oddani Bogu..., dz. cyt., s. 18-23.

6 J. W. Gogola, Teologia komunii z Bogiem, Kraków 20124, s. 17-21. 
Boży dar życia nadprzyrodzonego może przerodzić się w duchowość dzięki zdolności człowieka do transcendencji, przekraczania samego siebie. Interesuje nas oczywiście człowiek wierzący, który wchodzi w relację zarówno z rzeczywistością nadprzyrodzoną, jak i naturalną. Te relacje niejako rzeźbią jego konkretną duchowość. U podstaw jakiegokolwiek rodzaju duchowości chrześcijańskiej jest osobowa relacja człowieka z Bogiem, stąd określenie duchowości ogólnej jako formy „duchowego życia człowieka religijnego, zmierzającego do zjednoczenia z Bogiem...”7. Ruch ku Bogu modeluje wszystkie inne odniesienia. W tej sytuacji określenie duchowości życia konsekrowanego będzie w swej istocie identyczne z określeniem duchowości chrześcijańskiej w ogólności, z tą różnicą, że trzeba uzupełnić ją o sposób jej realizacji. Zatem duchowość życia konsekrowanego jest realizacją osobowej komunii człowieka z Bogiem na fundamencie konsekracji chrzcielnej i zakonnej oraz w harmonii z charyzmatem instytutu, do którego jest się powołanym ${ }^{8}$. Osobowa komunia z Bogiem realizowana jest dzięki cnotom teologalnym, natomiast specyfika tej komunii zależy od otrzymanego charyzmatu, który praktycznie oznacza określony sposób życia i apostołowania w Kościele. Duchowość jakiejkolwiek formy życia konsekrowanego musi czerpać ze zdrowej i głębokiej chrześcijańskiej duchowości (por. VC 93). Stąd podstawowymi środkami umacniania komunii z Chrystusem przez osobę konsekrowaną będą środki wspólne wszystkim Jego uczniom: Eucharystia, sakrament pokuty i pojednania, nieustanne nawrócenie, modlitwa, kierownictwo duchowe, pobożność maryjna (por. VC 93).

Antoni Nowak, usiłując zdefiniować duchowość życia konsekrowanego, stwierdza, że duchowość osób konsekrowanych jest duchowością „eklezjalną, sakramentalną, eucharystyczną, maryjną, rad ewangelicznych, eschatyczną, charyzmatyczną, petryczną" (od Petrusa) ${ }^{9}$. Jak łatwo zauważyć, przeważają tu cechy każdej duchowości chrześcijańskiej i ten fakt jest godny podkreślenia. Duchowość życia konsekrowanego nie stanowi w Kościele jakiejś enklawy mającej niewiele wspólnego z innymi wierzącymi. Przeciwnie, re-

\footnotetext{
M. Daniluk, Duchowośćchrześcijańska, [w:] Encyklopedia katolicka, t. 4, pod red. R. Łukaszyka, Lublin 1983, kol. 317; M. Chmielewski, Sto jeden pytań o życie duchowe, Lublin 1999, s. 11-12.

Por. J. W. Gogola, Oddani Bogu, s. 20.

A. J. Nowak, Homo consecratus, Lublin 2002, s. 73.
} 
prezentuje sobą te cechy wspólnego powołania do świętości, które są najbardziej podstawowe. Z punktu widzenia teologicznego to, co jest wspólne powołaniu wszystkich stanów życia w Kościele, jest czymś zdecydowanie większym niż różnice.

Na kolejnym etapie refleksji można pokusić się o precyzyjne oddzielenie tych elementów, które są nieodzowne dla każdej formy życia zakonnego. W nauczaniu Kościoła poprzedzającym Vita consecrata zostały one wymienione i omówione w specjalnej instrukcji o istotnych elementach życia zakonnego ${ }^{10}$. Chodzi o takie elementy, jak: powołanie zakonne, konsekracja, rady ewangeliczne, życie wspólne, odpowiedni sposób zarządzania i formacji, odpowiedni stosunek do świata, specyficzna forma ascezy i modlitwy. Wszystkie te elementy można sprowadzić do dwóch: konsekracji i charyzmatu instytutu. Konsekracja reprezentuje wszystkie istotne elementy życia konsekrowanego, natomiast charyzmat dodatkowo wpływa na ostateczny kształt przeżywania tego, co wspólne tego rodzaju powołaniom. Zagadnienia te zostały już w sposób wyczerpujący przestudiowane ${ }^{11}$. W odniesieniu do istotnych elementów życia zakonnego trzeba zauważyć, że są one wspólne wszystkim instytutom, w związku z tym nauczanie papieskie dotyczy wszystkich form życia konsekrowanego. Natomiast specyficzny charyzmat może być jedynie ogólnie opisany i zastosowany do instytutów, zaś jego ostateczna forma musi być rozeznana w konkretnej wspólnocie, która go otrzymała od Boga dla służby Kościołowi.

\section{Tożsamość życia konsekrowanego}

Temat to żs a mości życia konsekrowanego jest obecny w założeniach Vita consecrata i w samym tytule adhortacji: „... życiu konsekrowanym

10 Kongregacja Zakonów i Instytutów Świeckich, Instrukcja o istotnych elementach nauczania Kościoła na temat życia konsekrowanego w zastosowaniu do instytutów oddających się pracy apostolskiej The renewal of religious life (31 maja 1983), [w:] Życie konsekrowane w dokumentach Kościoła, s. 289-315 [dalej: EE].

11 Por. np. T. Paszkowska, Charyzmat życia konsekrowanego, [w:] „Vita consecrata”. Adhortacja. Tekst $i$ komentarze, red. A. J. Nowak, Lublin 1998, s. 325-342; J. W. Gogola, Oddani Bogu, dz. cyt., s. $65-78,122-130$. 
i jego misji”, innymi słowy: o tożsamości życia konsekrowanego i jego misji w Kościele i świecie. Od tego, czym jest życie konsekrowane w Kościele, zależy bowiem zajmowane w nim miejsce oraz misja.

Istnieje ścisły związek pomiędzy konsekracją, komunią i misją a tożsamością. Teolodzy, chcąc ukazać tożsamość osób konsekrowanych, poruszają dokładnie te same tematy ${ }^{12}$. Tożsamość ofiarowana wraz z łaską powołania (ludzkiego, chrześcijańskiego i zakonnego) wymaga asymilacji przez współpracę (modlitwa, asceza). Z tożsamości pełnej i bogatej w sposób spontaniczny i niejako naturalny wypływa misja, która polega przede wszystkim na świadectwie życia. „Apostolstwo wszystkich zakonników polega na świadectwie ich życia konsekrowanego, które winni ożywiać modlitwą i pokutą"13. Modlitwa i asceza nie figurują w adhortacji jako tematy osobnych rozdziałów, gdyż przynależą zarówno do tożsamości, jak i do misji. Te same działania, które decydują o asymilacji i wzrastaniu we własnej tożsamości konsekrowanej, decydują jednocześnie o jej owocności.

Rzecz godna podkreślenia: wyjątkowość powołania do życia konsekrowanego jest zawsze podkreślana z myślą o całym Kościele i świecie. Przykładem może tu być powołanie się na zdanie św. Teresy Wielkiej: „Cóż by było ze światem, gdyby zabrakło w nim dusz życiu zakonnemu poświęconych?”"14. Komisja soborowa opracowująca dekret Perfectae caritatis opowiedziała się za typologicznym tylko opisem zakonów, a nie jednoznacznym określeniem i uchyliła odnośny wniosek, motywując, że Sobór nie może podać jednoznacznej definicji życia zakonnego, jeżeli teologowie nie są zgodni w tej sprawie ${ }^{15}$.

Taka próba, mająca charakter bardzo ogólny, nie uwzględnia różnic pomiędzy poszczególnymi instytutami zakonnymi. Joseph Aubry stara się ją zrealizować, konfrontując życie konsekrowane z dwoma zagadnieniami:

12 Zob. L'identità dei consacrati nella missione della chiesa e il loro rapporto con il mondo, a cura dell'Istituto Claretianum, Cità del Vaticano 1994.

13 KPK, kan. 673.

14 Ksiega życia 32, 11; Jan Paweł II, adhort. apost. Vita consecrata, 105 (przypis adhortacji w polskim tłumaczeniu błędnie odsyła do św. Teresy z Lisieux).

15 Zob. K. Hołda, Życie konsekrowane, Warszawa 1979, s. 12, przypis 1. 
powołaniem do świętości i relacjami pomiędzy stanem zakonnym, laikatem i kapłaństwem ${ }^{16}$.

\subsection{Stan zakonny a powołanie do świętości}

Zakotwiczenie życia zakonnego w Kościele dokonuje się w pierwszym rzędzie poprzez sakramenty Kościoła. Nie istnieje jednak specjalny sakrament, który wprowadzałby do stanu zakonnego, jak to jest w przypadku kapłaństwa i małżeństwa. Joseph Aubry tłumaczy to w sposób następujący ${ }^{17}$ : sakramenty umieszczają wierzącego w sytuacji całkowicie nowej w stosunku do poprzedniej albo też przydzielają mu zupełnie nową funkcję. Kapłan poprzez sakrament kapłaństwa przynależy do hierarchii Kościoła; kobieta i mężczyzna zawierający sakrament małżeństwa stają się chrześcijańskimi małżonkami: wyrażają w sposób widzialny relację miłości pomiędzy Chrystusem i Kościołem oraz rodzą nowych członków Kościołowi. Zakonnik natomiast nie znajduje się w radykalnie nowej sytuacji w Kościele ani nie wypełnia radykalnie nowej funkcji, ale pełniej realizuje powołanie całego Kościoła. Wynika z tego, że życie zakonne musi nawiązywać do podstawowych sakramentów Kościoła, dzięki którym człowiek staje się chrześcijaninem - chrztu, bierzmowania - i pociąga za sobą szczególnego rodzaju odpowiedź na wymagania tych sakramentów.

Formuła profesji, w której zakonnik wyrzeka się wszystkiego, by pójść za Chrystusem, jest podjęciem zobowiązania chrzcielnego, w którym chrześcijanin wyrzeka się szatana i wszystkich jego spraw, a łączy się na zawsze z Chrystusem. Konsekracja zakonna powoduje głębsze zakorzenienie w łasce chrześcijańskiego powołania i umożliwia jego bogatszy wyraz ${ }^{18}$. Nie idzie dalej, niż umożliwia to chrzest. Stąd profesja zakonna nie stwarza superchrześcijanina. Zakonnicy nie stanowią chrześcijańskiej arystokracji obdarowanej szczególnymi przywilejami i wyjątkowymi prawami. Stanowią natomiast szczególnie żywy wyraz powszechnego powołania.

16 Por. J. Aubry, Teologia della vita religiosa, Torino 1988, s. 11-19; J. W. Gogola, Oddani Bogu, dz. cyt., s. 58-64.

17 Por. J. Aubry, Teologia della vita religiosa, dz. cyt., s. 13-14.

18 Sobór Watykański II, konst. Lumen gentium [dalej: LG], 44a, dekret Perfectae caritatis [dalej: PC], 5a. 
Trzeba jednak zapytać o oryginalność życia zakonnego. Odpowiedź znajduje się już w tytule rozdziału VI Konstytucji dogmatycznej o Kościele: oryginalność wynika z drogi i z rodzaju środków, z jakich korzystają zakonnicy. O ile istota życia chrześcijańskiego jest taka sama dla wszystkich (miłość do Boga i bliźniego) i cel ten sam (doskonałość miłości), drogi prowadzące do niej są różne, różne są uwarunkowania codziennego życia i różny jest stopień odpowiedzialności za Kościół, zależny od pełnionych funkcji19. Zatem mogą istnieć w Kościele różne konkretne powołania, których celem jest ta sama świętość.

Istnieją w Kościele komplementarne drogi świętości, różniące się między sobą, choć wszystkie autentyczne. Laikat osiąga świętość w świecie i dla świata (por. LG 31). Droga osób konsekrowanych opisana jest w pierwszych linijkach dekretu Perfectae caritatis: „Dążenie do miłości doskonałej drogą rad ewangelicznych...” (PC 1); „Perfectae caritatis prosecutio [taki jest cel wszystkich ochrzczonych] per consilia evangelica [taka jest droga właściwa zakonnikom]".

Ta sama świętość, ta sama ewangeliczna miłość mają być realizowane także w innych warunkach życia, by mógł być realizowany jeszcze inny aspekt życia Kościoła. Zakonnik jest chrześcijaninem, który wyrzeka się życia świeckiego ze względu na królestwo niebieskie (Mt 19, 12), „by troszczyć się o sprawy Pana" (1 Kor 7, 32). Odsuwa się zatem od zwykłych warunków życia i w instytucie życia konsekrowanego rozpoczyna nowy sposób egzystencji. Tutaj nie chodzi już o przeżywanie sytuacji życiowych pośród świata przez przepajanie ich duchem ewangelicznym. Zakonnik wchodzi w nowe struktury życia. Zakonnicy mają do spełnienia w Kościele pewną misję. Polega ona m.in. na tym, by uświadomić wszystkim wierzącym, że Boga nie można utożsamiać z wartościami ziemskimi, Jego łaska nie wypływa z ziemskich wartości ani z samego ludzkiego wysiłku. Bóg jest najwyższą wartością. Aby to ukazać, zakonnik zostaje postawiony w sytuacji, w której może łatwiej się z Nim zjednoczyć. Życie zakonne ukazuje transcendentny wymiar łaski Chrystusowej, natomiast życie świeckie ma przemieniać świat, przygotowując go na przyjście Pana ${ }^{20}$.

19 Por. J. Aubry, Teologia della vita religiosa, dz. cyt., s. 16.

20 J. Aubry, Teologia della vita religiosa, dz. cyt., s. 19. 


\subsection{Stan zakonny a charyzmatyczna struktura Kościoła (LG 44)}

Podział wierzących na trzy stany - kapłanów, osoby świeckie i zakonników - bierze się z dwojakiego rodzaju spojrzenia na Kościół: hierarchicznego i charyzmatycznego. Z punktu widzenia hierarchicznego Kościół dzieli się na kapłanów i niekapłanów, czyli laikat w szerokim znaczeniu. Biskupi, prezbiterzy i diakoni reprezentują Chrystusa Głowę. Budują Kościół poprzez głoszenie Słowa i sprawowanie sakramentów. Jest też punkt widzenia charyzmatyczny. Duch Święty wzbudza w Kościele charyzmaty, dzięki którym życie całego Kościoła przybiera postać odpowiedzi na Boże powołanie w dwóch podstawowych formach: życia pośród świata (katolicy świeccy) i życia w oddzieleniu od świata (zakonnicy). Członkowie hierarchii mogą należeć do jednej lub drugiej grupy.

Dla lepszego usytuowania zakonnika w Kościele możemy zestawić jego sytuację z sytuacją zarówno kapłana, jak i osoby świeckiej. Wobec kapłana zakonnik jest w podobnej sytuacji co osoba świecka, gdyż tak jak ona dąży do tej samej świętości chrzcielnej, chociaż na inny sposób. Zakonnik nie należy do hierarchii. $\mathrm{Z}$ historii wiadomo, że pierwsze rodziny zakonne, np. wspólnota św. Benedykta i jego uczniów, składały się z „braci”. Tak osoba konsekrowana, jak i świecka podlegają władzy kościelnej. Zakonnikjest jednakże bardzo podobny do kapłana i podobnie jak on jest w innej sytuacji niż osoba świecka, która jest całkowicie zanurzona w świecie. Zauważmy jednak, że w tym momencie uwzględniamy warunki życia, nie cel do osiągnięcia (LG 31 skupia się na płaszczyźnie praktycznej).

Kapłan także musi znajdować się w pewnym oddaleniu od świata. Jego sposób życia może być podobny do katolika świeckiego, w niektórych rytach Kościoła mógłby się nawet ożenić czy wykonywać zawód. Jednak nie może całkowicie upodobnić się do osoby świeckiej ani całkowicie oddać się działalności ziemskiej (LG 31). Zatem przynajmniej częściowo jest oddzielony od świata i przez to upodobniony do zakonnika, zwłaszcza na Zachodzie z racji celibatu.

W historii te dwa rodzaje duchowości uzależniły się wzajemnie od siebie. Kapłan za bardzo oddalił się od laikatu i jego styl życia uległ wpływom środowisk zakonnych. Zakonnicy natomiast poczuli dużą atrakcyjność kapłaństwa. Stąd należy przypomnieć, że życie zakonne może być przeżywane w całej pełni bez kapłaństwa. 


\section{Charakterystyczne rysy duchowości życia konsekrowanego}

Adhortacja Vita consecrata zawiera trzypunktową strukturę, która bardzo dobrze nadaje się do przedstawienia zasadniczych rysów duchowości życia konsekrowanego ${ }^{21}$. Oprócz wstępu i zakończenia składają się na nią trzy rozdziały, traktujące odpowiednio o konsekracji, komunii i misji, nazwanych przez Jana Pawła II trzema wymiarami życia konsekrowanego (zob. VC 13). Rozdział I nosi tytuł Confessio Trinitatis (Wyznanie Trójcy Świętej). Z proklamacją misterium Trójcy Świętej związana została cała rzeczywistość życia konsekrowanego: jego powstanie i rozwój, od trynitarnych i chrystologicznych korzeni, poprzez Paschę do jej wypełnienia w Kościele i dla Kościoła, pod przewodnictwem Ducha Świętego. O komunii traktuje rozdział II: Signum fraternitatis (Znak braterstwa), który przypomina prawdę, że życie konsekrowane umiejscawia się w sercu Kościoła jako znak dla wszystkich, że Kościół to przede wszystkim komunia osób realizowana w Chrystusie mocą Ducha. Rozdział III: Servitium caritatis (Posługa miłości), już przez sam tytuł poucza, że poprzez życie konsekrowane ujawnia się i działa miłość Boga do świata. Chodzi nie tylko o wykonywanie właściwych sobie zadań w duchu miłości, ale także o profetyczną obecność w świecie i podejmowanie wyzwań, jakie stawia on wszystkim wierzącym.

Te trzy wielkie rzeczywistości życia konsekrowanego są ze sobą ściśle powiązane. Tematem wiodącym, przywołującym dwa pozostałe, jest oczywiście konsekracja. Treść tych rzeczywistości życia konsekrowanego nie jest nowa. Na uwage zasługuje natomiast ich ograniczenie do trzech i powiązanie z pozostałymi elementami życia konsekrowanego. Dokument Kongregacji Zakonów i Instytutów Świeckich z 1983 roku Istotne elementy nauczania Kościoła na temat życia konsekrowanego... na pierwszym miejscu wymienia właśnie te trzy, dodając do nich modlitwę, ascezę, publiczne świadectwo, związek z Kościołem i odpowiednie dla natury życia ewangelicznego zarządzanie, formację $e^{22}$. Na szczególną uwagę zasługuje tu wyeksponowanie tematu komunii z Kościołem. Jest to jedna z nowości obecna w teolo-

${ }^{21}$ Por. J. W. Gogola, Wstęp do adhortacji ,Vita consecrata”, [w:] Jan Paweł II, Adhortacje, Kraków 2006, s. 491-494 (Dzieła Zebrane, 2).

22 Por. EE 13-52. 
gii życia konsekrowanego już od Vaticanum II. Teologia życia konsekrowanego osadzona jest w eklezjologii, głównie eklezjologii komunii, samo zaś życie konsekrowane staje się znakiem eklezjalnej komunii. Adhortacja Vita consecrata traktuje także o pozostałych charakterystycznych elementach życia konsekrowanego, czyni to jednak w ramach wymienionej potrójnej rzeczywistości.

Trzy rozdziały to najbardziej podstawowe wymiary chrześcijańskiej duchowości: trynitarny, eklezjalny i apostolski. Wspaniała synteza wszystkich istotnych elementów życia zakonnego, a jednocześnie zachowanie głębokiej komunii z pozostałymi stanami życia w Kościele ${ }^{23}$.

\subsection{Konsekracja}

Rozdział I Confessio Trinitatis zawiera cztery zasadnicze punkty: „Na chwałę Trójcy Przenajświętszej” (17n), „Między Paschą a pełnią czasów” (23n), „W Kościele i dla Kościoła” (29-34) oraz „Prowadzeni przez Ducha Świętości" (35-40).

Na mocy szczególnego, tj. wyjątkowego, powołania, poprzez konsekrację we wspólnocie Kościoła, osoba staje się zdolna do „egzystencji na wzór Chrystusa" (VC 14). W powołanie i jego rozwój zaangażowane są trzy Osoby Boskie: osoba zostaje pociągnięta przez Ojca do pójścia drogą radykalnego naśladowania Chrystusa dzięki darowi Ducha Świętego. Wyraża to rozpracowana w adhortacji formuła łacińska: „A Patre ad Patrem, per Filium in Spiritu” (VC 17-20). Z tej racji „pierwszym zadaniem życia konsekrowanego jest ukazywanie wielkich dzieł, jakich Bóg dokonuje w ułomnej ludzkiej naturze powołanych" (VC 20). Mają zaś tego dokonywać własnym stylem życia, czyli duchowością. Szczególne odniesienie do życia duchowego zawarte jest w części IV tego rozdziału: „Prowadzenie przez Ducha Świętego”, gdzie figuruje punkt: „Życie «przemienione»: wezwanie do świętości” (VC 35). Lapidarne sformułowanie, obecne już w Lumen gentium: powołanie do świętości, przybiera tu formę „powołania do przemienionego życia” na wzór Chrystusa (VC 35). Całą egzystencję konsekrowaną winien cechować dyna-

${ }^{23}$ Por. wyczerpujące studium na ten temat: C. Parzyszek, Życie konsekrowane w posoborowym nauczaniu Kościoła, Ząbki 2007, zwłaszcza s. 476-596. 
mizm poszukiwania wierności Ewangelii i własnemu charyzmatowi. $\mathrm{W}$ tym kontekście pada słynne wyrażenie: „,wierność twórcza” (VC 37), które zmusza do rewizji wielu postaw jedynie zachowawczych.

Konsekracja, wbrew utartym schematom myślowym, nie może skupiać osoby powołanej jedynie na Bogu, ale powinna czynić osobę człowiekiem zatroskanym o świętość życia innych. Osoby konsekrowane bowiem „z samej natury życia zakonnego przynależą do dynamicznej działalności Kościoła, który gorąco pożąda «Absolutu», jakim jest Bóg, i jest wezwany do świętości. Zakonnicy są świadkami tej świętości”. Fakt, że wszyscy są powołani do świętości, musi stanowić dodatkowy bodziec dla tych, którzy ze względu na wybraną drogę życia powinni przypominać o tym innym (VC 39).

W adhortacji konsekracja zakonna ukazana jest w kontekście komunii z Kościołem i światem. Jest ona darem dla Kościoła, a poprzez Kościół dla świata. „Profesja rad ewangelicznych jest integralną częścią życia Kościoła” (VC 3).

\subsection{Komunia}

Rozdział II Signum fraternitatis należy uznać za jedno z najbardziej istotnych zagadnień w całej posoborowej odnowie życia zakonnego. Mowa w nim o komunii i braterstwie ${ }^{24}$ jako oczywistym kontekście realizowania wszelkich ewangelicznych powołań. Jest to bezpośrednie nawiązanie do Kościoła komunii, który stanowią bardzo liczne wspólnoty osób wierzących na całym świecie, które z kolei powinny być fermentem komunii dla innych. Duchowość komunii to jedno z genialnych wyrażeń, jakie znajdziemy w VC. „Kościół jest w swej istocie tajemnicą komunii, «ludem zgromadzonym przez jedność Ojca, Syna i Ducha Świętego». Życie braterskie ma odzwierciedlać głębię i bogactwo tej tajemnicy, tworząc ludzką przestrzeń zamieszkałą przez Trójcę Przenajświętszą, która w ten sposób rozlewa w historii dary komunii, właściwe dla trzech Boskich Osób” (VC 41). Powołanie do świętości i duchowość osób konsekrowanych zostaje niejako naznaczona cechą eklezjalnej komunii. W takim kontekście pada chyba po

${ }^{24}$ Por. studium naukowe na temat braterstwa w Piśmie Świętym i nauczaniu Kościoła w odniesieniu do osób konsekrowanych: T. Paszkowska, „Fraternitas”. Od pragnienia do urzeczywistnienia, Lublin 2013. 
raz pierwszy wyrażenie, które powinno stać się programem świętości dla całego Kościoła: „....gorąco pragnę, aby wzrastała we wszystkich świadomość i duchowość komunii" (VC 50) ${ }^{25}$. Właśnie przez pryzmat komunii winny być odczytywane wszystkie elementy życia konsekrowanego, wszystkie funkcje i zadania, a także konkretne problemy życia codziennego, jak obecność osób starszych we wspólnocie (VC 44), zadania władzy (VC 43) czy dialog wewnątrz wspólnot i pomiędzy różnymi instytucjami Kościoła (VC 50). Z komunijnej rzeczywistości życia konsekrowanego wypływa także odpowiednie zadanie w stosunku do Kościoła i świata:

Kościół powierza wspólnotom życia konsekrowanego szczególną troskę o wzrost duchowości komunii przede wszystkim wewnątrz nich samych, a następnie w łonie kościelnej wspólnoty i poza jej obrębem: mają ją szerzyć, nawiązując lub podejmując wciąż na nowo dialog miłości ze światem, zwłaszcza tam, gdzie toczą się dziś konflikty etniczne lub szaleje śmiercionośna przemoc (VC 51).

Zadanie, jakie spoczywa na Kościele, zostaje tu przekazane wszystkim instytutom zakonnym, co jedynie potwierdza prawdę o obecności życia konsekrowanego w sercu Kościoła i o istotnej jego reprezentacji.

\subsection{Misja}

Trzecia część adhortacji Vita consecrata nosi tytuł Servitium caritatis [Służba miłości]. Streszczenie zasadniczych idei adhortacji zawiera się w tytułach części III: Miłość aż do końca (75), Świadectwo prorockie w obliczu wielkich wyzwań (84), Niektóre areopagi misji (96). Trzy zasadnicze działy wyrażają odpowiednio istotę misji osób konsekrowanych, a właściwie wszystkich chrześcijan - miłość; formę misji - prorockie świadectwo; oraz najważniejsze miejsca dawania tego świadectwa ${ }^{26}$.

Już sam fakt, że misji zakonników w Kościele poświęcono tak wiele miejsca, świadczy o właściwym kierunku rozumienia powołania osób konsekrowanych. W okresie posoborowym dokonuje się przezwyciężanie dominują-

25 Por. J. Castellano Cervera, Dimensione teologica e spirituale della vita consacrata: tradizione, novità, profezia, dz. cyt., s. 58.

${ }_{26}$ Zob. szczegółowe opracowanie tej problematyki: J. W. Gogola, Oddani Bogu, dz. cyt., s. $234-247$. 
cej przez wieki duchowości indywidualistycznej uprawianej pod szyldem „stanu doskonałości”, w jakim mieli znajdować się zakonnicy. W adhortacji już w sposób wybitny mamy do czynienia z doskonałą synchronizacją powołania i misji osób konsekrowanych z powołaniem i misją całego Kościoła.

Misję osób konsekrowanych można ująć w wyrażeniu: „charyzmat prorockiego świadectwa”. Już na soborze była mowa o „znaku”, jakim życie konsekrowane winno być dla innych. Ma ono być znakiem „życia nowego i wiecznego", przepowiadaniem przyszłego zmartwychwstania i chwały nieba, objawiać wyższość królestwa Chrystusowego ponad wszelkimi dobrami tej ziemi (por. LG 44). Kluczowy pod tym względem tekst znajduje się w Evangelii nuntiandi:

Z samej natury życia zakonnego przynależą oni [zakonnicy] do dynamicznej działalności Kościoła, który gorąco pożąda „Absolutu”, jakim jest Bóg, i ma powołanie do świętości. Zakonnicy są świadkami tej świętości, gdyż wyrażają sobą Kościół, o ile pragnie on poświęcenia się spełnianiu surowych wymagań Błogosławieństw. Poprzez swój sposób życia są znakiem całkowitego oddania się na służbę Bogu, Kościołowi i braciom. Z tego powodu osoby zakonne mają szczególne znaczenie, gdy chodzi o to świadczenie, o którym mówiliśmy wyżej, że stanowi jeden z pierwszych elementów ewangelizacji. To milczące świadczenie o ubóstwie i oderwaniu od rzeczy tego świata, o czystości i niewinności życia, o woli przystającej na posłuszeństwo, stanowi wyzwanie wobec świata, a nawet wobec samego Kościoła, a ponadto może stać się pewną otwartą formą przepowiadania, która zdolna jest poruszyć także niechrześcijan, ludzi dobrej woli, przywiązujących wagę do wartości duchowych (EN 69).

Aluzja do tego tekstu, po latach ignorowania go, pojawi się aż pięciokrotnie w Vita consecrata ${ }^{27}$. Adhortacja po raz pierwszy w tak klarowny sposób przedstawia misję życia konsekrowanego w kategoriach „proroctwa” (VC 84), a nawet pozwala mówić o duchowości profetycznej w nawiązaniu do misji Chrystusa, ale także do wielkich proroków Starego Przymierza, takich jak Eliasz. Profetyzm rodzi się z modlitwy rozumianej jako przyjaźń z Bogiem, a wyraża się w ewangelicznym autentyzmie, w braterskiej komunii i współpracy z całym Kościołem, a nawet w męczeństwie, co jeszcze dzisiaj zdarza się w różnych zakątkach świata ${ }^{28}$.

27 VC 3, 39, 76, 77, 108.

28 Por. J. Castellano Cervera, Dimensione teologica e spirituale della vita consacrata: tradizione, novità, profezia, dz. cyt., s. 60. 
Jacek Kiciński jednej ze swoich teologicznych rozpraw bardzo szczęśliwie daje tytuł Duchowość misji współdzielonej, wskazując tym samym na jedną misję Kościoła, w której uczestniczą wszystkie stany życia ${ }^{29}$. Duchowość osób konsekrowanych nie jest jedynie jakimś zapleczem duchowym dla duchowieństwa i laikatu, ale reprezentuje cały Kościół w specyficzny dla siebie sposób ${ }^{30}$.

\section{Synteza}

Duchowość życia konsekrowanego kształtowana jest przez wiele czynników o charakterze naturalnym i nadprzyrodzonym. Jest przejawem ducha człowieka, który jest autentycznym chrześcijaninem, a więc osobą, która w Chrystusie odnalazła najgłębszy sens swojego życia, a w Kościele miejsce swojego życia i apostołowania. Adhortacja Vita consecrata bardzo szczęśliwie porządkuje wszystkie czynniki duchowości w trzy grupy: konsekrację, wspólnotę, misję, czemu odpowiadają trzy wymiary wszelkiej chrześcijańskiej duchowości: trynitarny, eklezjalny i apostolski, wyrażając na pierwszym miejscu odniesienie do Boga objawienia, do Kościoła jako „miejsca” przeżywania swojej relacji z Bogiem i z braćmi Chrystusa i do świata jako areopagu, tj. niejako sceny, na której rozgrywa się walka o zbawienie i uświęcenie człowieka.

Jan Paweł II w omawianej adhortacji przedstawia każdą z tych rzeczywistości w ścisłej jedności z pozostałymi, a życie konsekrowane jako życie Kościoła komunii. Duchowość osoby konsekrowanej kształtowana jest najpierw przez bliską relację z Osobami Trójcy Świętej, w której należy przez cały czas bronić prymatu łaski; przez świadomość bycia Kościołem, jego żywą cząstką, z wyjątkowym miejscem (w jego sercu) i ewangelizacyjnymi zadaniami do wypełnienia. Osoba konsekrowana jawi się tu jako przyjaciel Boga, uczeń przemieniony blaskiem przemienionego Chrystusa, chrześcija-

29 J. Kiciński, Duchowość misji współdzielonej. Studium w świetle współczesnego Magisterium Kościoła, Wrocław 2013.

30 Por. B. Giemza, Apostolski wymiar życia konsekrowanego w nauczaniu Jana Pawła II. Studium teologicznopastoralne, Wrocław 2012; S. Zarzycki, Apostolski charakter życia zakonnego, [w:] „Vita consecrata". Adhortacja. Tekst $i$ komentarze, red. A. J. Nowak, dz. cyt., s. 383-406. 
nin mający mentalność komunii i żyjący duchowością komunii, prorok znający dobrze język Boga i jednocześnie człowiek dialogu wewnątrz własnej wspólnoty, Kościoła i ad extra.

Ten trzypunktowy schemat można by równie dobrze odnieść do dwóch pozostałych stanów życia i na jego podstawie omówić ich specyficzną duchowość. Oznacza to pewne utrudnienie w uchwyceniu specyficznych rysów duchowości osób konsekrowanych, a jednocześnie stanowi bardzo pozytywny fakt świadczący o tym, że nie są one jakąś enklawą w Kościele, ale posiadają wspólne wszystkim powołanie do świętości realizowanej w Kościele i na arenie świata. Specyfika, którą chcemy określić, nie wiąże się z płaszczyzną podstawowych odniesień (Bóg, wspólnota, świat), ale dotyczy charakterystycznego sposobu przeżywania tych odniesień, zależnego przede wszystkim od charyzmatu instytutu. 


\section{Summary}

The spirituality of consecrated persons

in the light of exhortation Vita consecrata of John Paul II

The reflection takes into account problems contained in the subject, concentrate on its three fundamental parts of components: the conception of the spirituality of the consecrated life, its identity from which results the whole lifestyle, and called actions, in accordance with rules: agere sequitur esse, and on representative its features reduce. in compliance with the exhortation structure Vita consecrata to three: the consecration, communion and the mission. The spirituality we treat as the sign of the spirit of Christ's follower, called the special vocation for radical following with Him on the way of the monastic consecration. Therefore this is also the external sign of the spirit, there is essential the identity of the person who should exist in the way "worthy of vocation", and thereby bear witness the saving presence of God in the today's world, in the way almost unintentional. There are three characteristic features of spirituality of the consecrated person simultaneously determine her identity: the person devoted of God by the profession of the evangelical counsels; the person of communion with God and brothers, and prophet-witness of great God's works, which are realized in the weak human. The whole is crowned by the short synthesis which may constitute only some advice on the subject this composed reality, and the invitation to building of this synthesis by individual consecrated persons, and their communities on the existential plane.

Keywords: Vita consecrata, the consecrated life, the spirituality, the spirituality of communion, the spirituality of consecrated persons, the consecration, communion, the mission, the identity of consecrated persons.

\section{Duchowość osób konsekrowanych}

w świetle adhortacji Jana Pawła II Vita consecrata

Refleksja uwzględnia problematykę zawartą w temacie, skupiając się na jego trzech zasadniczych składowych: koncepcji duchowości życia konsekrowanego, jego tożsamości, z której wynika styl życia i działania powołanych w myśl zasady: ,agere sequitur esse”, oraz na jej reprezentacyjnych cechach sprowadzonych za przykładem struktury adhortacji Vita consecrata do trzech: konsekracja, komunia i misja. Duchowość traktujemy jako przejaw ducha ucznia Chrystusa wezwanego szczególnym powołaniem do radykalnego pójścia za Nim drogą zakonnej konsekracji. Ponieważ jest to także zewnętrzny przejaw ducha, istotna jest tożsamość osoby, która powinna egzystować w sposób „godny powołania”, a przez to dawać świadectwo zbawczej obecności Boga w dzisiejszym świecie w sposób niemal bezwiedny. Trzy cechy charakterystyczne duchowości osoby konsekrowanej określają jednocześnie jej tożsamość: osoba oddana przez śluby rad ewangelicznych Bogu; osoba komunii z Bogiem i braćmi oraz prorok-świadek wielkich dzieł Bożych, które realizują się 
w słabym człowieku. Całość wieńczy krótka synteza, która może stanowić jedynie pewną wskazówkę na temat tej złożonej rzeczywistości i zaproszenie do budowania tej syntezy na płaszczyźnie egzystencjalnej przez poszczególne osoby konsekrowane i ich wspólnoty.

Słowa kluczowe: Vita consecrata, życie konsekrowane, duchowość, duchowość komunii, duchowość osób konsekrowanych, konsekracja, komunia, misja, tożsamość osób konsekrowanych.

\section{Bibliografia}

Aubry J., Teologia della vita religiosa, Torino 1988.

Cabra P. G., Presentazione del documento „Vita consecrata”, [w:] L'esortazione apostolica post-sinodale di Giovanni Paolo II „Vita consecrata”. I grandi temi, Roma 1997, s. 7-32.

Castellano Cervera J., Dimensione teologica e spirituale della vita consacrata: tradizione, novità, profezia, [w:] Vita consecrata, autori vari, Roma 1996, s. 35-67.

Chmielewski M., Sto jeden pytań o życie duchowe, Lublin 1999.

Daniluk M., Duchowośćchrześcijańska, [w:] Encyklopedia katolicka, t. 4, pod red. R. Łukaszyka, L. Bieńkowskiego i F. Gryglewicza, Lublin 1983, kol. 317-330.

Giemza B., Apostolski wymiar życia konsekrowanego w nauczaniu Jana Pawła II. Studium teologicznopastoralne, Wrocław 2012.

Gogola J. W., Oddani Bogu. Teologia i duchowość życia konsekrowanego, Kraków 2013.

Gogola J. W., Teologia komunii z Bogiem. Synteza teologii duchowości, Kraków 2012².

Gogola J. W., Wstęp do adhortacji „Vita consecrata”, [w:] Jan Paweł II, Adhortacje, Kraków 2006, s. 491-494 (Dzieła Zebrane, 2).

Hołda K., Życie konsekrowane, Warszawa 1979.

Kiciński J., Duchowość misji współdzielonej. Studium w świetle współczesnego Magisterium Kościoła, Wrocław 2013.

Kongregacja Zakonów i Instytutów Świeckich, Instrukcja o istotnych elementach nauczania Kościoła na temat życia konsekrowanego w zastosowaniu do instytutów oddających się pracy apostolskiej The renewal of religious life (31 maja 1983), [w:] Życie konsekrowane w dokumentach Kościoła, opr. B. Hylla, Kraków 2003, s. 289-315.

L'identità dei consacrati nella missione della chiesa e il loro rapporto con il mondo, a cura dell'Istituto „Claretianum”, Cità del Vaticano 1994.

Nowak A. J., Homo consecratus, Lublin 2002.

Paszkowska T., Charyzmat życia konsekrowanego, [w:] „Vita consecrata”. Adhortacja. Tekst $i$ komentarze, red. A. J. Nowak, Lublin 1998, s. 325-342.

Paszkowska T., „Fraternitas”. Od pragnienia do urzeczywistnienia, Lublin 2013.

Parzyszek C., Życie konsekrowane w posoborowym nauczaniu Kościoła, Ząbki 2007.

Zarzycki S., Apostolski charakter życia zakonnego, [w:] „Vita consecrata”. Adhortacja. Tekst i komentarze, red. A. J. Nowak, Lublin 1998, s. 383-406. 